\title{
The Relationship Between Cognitive Styles and Young Adult Learners' Preferences for Written Corrective Feedback
}

\section{La relación entre los estilos cognitivos y las preferencias de retroalimentación correctiva escrita de los estudiantes"}

\author{
Negar Moslemi \\ moslemi.negar@iausdj.ac.ir \\ Adel Dastgoshadeh \\ adastgoshadeh@iausdj.ac.ir \\ Islamic Azad University, Sanandaj, Iran
}

This study aimed to investigate the relationship between learners' cognitive styles and their preferences for different types and frequencies of written corrective feedback and for different types of errors to be corrected. Data were collected from 60 English as a foreign language learners at intermediate and upper-intermediate levels. The instruments included the Ehrman and Leaver Learning Styles Questionnaire, and a questionnaire constructed by Amrhein and Nassaji (2010). The results indicated that there is a strong relationship between learners' cognitive styles and their preferences for a particular type of written corrective feedback and for different types of errors to be corrected; but there is no significant relationship between cognitive styles and learners' preferences for frequencies of written corrective feedback.

Key words: Cognitive style, English as a foreign language, error type, written corrective feedback, young adult learners of English.

\footnotetext{
* $\quad$ Received: November 9, 2016. Accepted: March 22, 2017.

How to cite this article (APA 6th ed.):

Moslemi, N., \& Dastgoshadeh, A. (2017). The relationship between cognitive styles and young adult learners' preferences for written corrective feedback. HOW, 24(2), 11-34. http://dx.doi.org/10.19183/how.24.2.338.

This article is licensed under a Creative Commons Attribution-NonCommercial-NoDerivatives 4.0 International License. License Deed can be consulted at http://creativecommons.org/licenses/by-nc-nd/4.0/.
} 
Este estudio investiga la relación entre los estilos cognitivos de los estudiantes y sus preferencias respecto al tipo y frecuencia de la retroalimentación correctiva escrita, así como la corrección de distintos tipos de errores. Los datos se obtuvieron de 60 estudiantes de inglés como lengua extranjera en niveles intermedio e intermedio-superior. Los instrumentos de recolección de datos incluyen el cuestionario de estilos de aprendizaje de Ehrman y Leaver y un cuestionario diseñado por Amrhein y Nassaji (2010). Los resultados muestran que existe una acentuada relación entre los estilos cognitivos de los estudiantes y sus preferencias por un tipo particular de retroalimentación correctiva escrita y la forma como se corrigen distintos errores. Sin embargo, la relación entre los estilos cognitivos y la frecuencia de la retroalimentación no es significativa.

Palabras clave: inglés como lengua extranjera, estilo cognitivo, jóvenes aprendices de inglés, retroalimentación correctiva escrita, tipo de error.

\section{Introduction}

Writing is one of those skills that are considered to have a great importance in second language learning. According to Boughey (1997), writing cannot be naturally acquired; but it is learned through formal instruction. In the process of writing it is common for learners to make errors. As Brown (2000) argues, "inevitably learners will make mistakes in the process of acquisition, and that process will be impeded if they do not commit errors and then benefit from various forms of feedback on those errors" (p. 216). Therefore, the issue of corrective feedback comes into focus.

A great deal of research has examined the effectiveness of written corrective feedback (WCF). On the one hand, a group of researchers believe that corrective feedback is ineffective, time consuming, and even harmful (Kepner, 1991; Semke, 1984; Sheppard, 1992; Truscott, 1996, 1999). On the other hand, another group of researchers defend the use of corrective feedback and believe that giving feedback on students' written errors can help them improve the quality and accuracy of their written works (Ferris, 1999, 2003, 2004; Hedgcok \& Lefkowitz, 1994; Lee, 1997, 2004; Rahimi, 2009).

Students' attitude and perception toward the usefulness of WCF has attracted much attention recently (Amrhein \& Nassaji, 2010). Studies on second language learning (Ferris, 1995; Hedgcock \& Lefkowitz, 1994; Leki, 1991; Roberts, 1999) have shown that learners' opinion and preferences for certain types and frequency of error correction affect their use of it for learning. Although most learners need or wish to be corrected, many of them find some types of feedback frustrating or embarrassing. Teachers cannot make learners feel embarrassed or disappointed while being corrected. In addition, a great amount of teachers' feedback remains unnoticed and simply ignored by learners (Ferris, 1995; Lyster \& Ranta, 1997). 
A great deal of research has examined learners' perceptions towards WCF, but these studies are considered to be incomplete because factors affecting learners' preferences have rarely been investigated. Ferris (2010) suggests that further research could investigate the role of learners' contextual and individual differences. She believes that the lack of sufficient research on these aspects has been attributed to a large gap in WCF research. There are many factors that can influence learners' perceptions such as age, sex, level of proficiency, motivation, and their style of thinking. Among these individual factors cognitive factors seem to have an important role in the efficacy of feedback and writing development (Rahimi, 2015). One of these cognitive factors that has been left unexplored is learners' cognitive styles, which has been considered as "potentially important in second language acquisition" (Larsen-Freeman \& Long, 1991, p. 193). Therefore, the aim of this study is to investigate the relationship between cognitive styles and learners' preferences for WCF. This goal is realized through the following research questions:

1. Is there any relationship between learners' cognitive styles and their preferences for different types of WCF?

2. Is there any relationship between learners' cognitive styles and their preferences for different frequencies of error correction?

3. Is there any relationship between cognitive styles and learners' preferences for different types of errors to be corrected?

\section{Literature Review}

\section{Corrective Feedback in Second Language Acquisition}

One area in second language acquisition (SLA) that has always been a target of investigation for researchers is corrective feedback. According to Lightbown and Spada (1999), corrective feedback refers to "any indication to the learners that their use of target language [L2] is incorrect" (p. 172). A considerable amount of research has examined the effectiveness of corrective feedback in writing, and most recent studies have found positive and significant effects of WCF (Ferris, 2003, 2004; Lee, 2004; Rahimi, 2009). However, there has been little agreement on how to correct errors made by L2 learners.

Ellis (2009) has provided a typology of teacher options for correcting learners' linguistic errors in their written works. This typology consists of six basic strategies for providing written corrective feedback:

Direct corrective feedback. According to Ellis (2009), direct corrective feedback refers to the explicit provision of correct form by the teacher to the student, such as crossing out 
an unnecessary word or provision of the correct form or structure. This type of correction might be useful for learners with low levels of proficiency who are not capable of selfcorrecting the error.

Indirect corrective feedback. Indirect corrective feedback refers to indicating learners' errors without correcting them, such as underlining the error, providing comments without correction, or providing clues or directions. According to Ellis (2009) this type of correction can be done in two ways: (1) indicating and locating errors, (2) indication only.

Metalinguistic corrective feedback. In the case of metalinguistic corrective feedback the teacher provides the learner with some form of metalinguistic clue about the nature of the error (Ellis, 2009). These metalinguistic clues can take two forms: (1) use of error code which is using abbreviated labels for different errors, (2) providing brief grammatical descriptions.

Focused versus unfocused corrective feedback. This type of correction concerns whether the teacher corrects all the errors made by the learner (unfocused), or selects specific types of errors to correct (focused).

Electronic feedback. In this type of correction the teacher provides learners with examples of correct usage, using different software programs.

Reformulation. In this case the teacher provides a native-like reconstruction of learners' texts and gives them the opportunity to compare their own and the reformulated text (Ellis, 2009).

\section{E\&L Model of Cognitive Styles}

A brief review of literature revealed that an increasing number of cognitive style dimensions have emerged over the years. Based on these dimensions, many models which define cognitive style differently have been introduced (Curry, 1983; Ehrman \& Leaver, 2003; Riding \& Cheema, 1991) and each researcher uses one of these models in her/his studies. Based on these models, researchers can assess individuals' cognitive styles. Ehrman and Leaver (2003) proposed a comprehensive taxonomy of cognitive styles, called the E\&L construct (after their surnames). Their model consists of a superordinate construct, synoptic-ectenic and ten subscales. Synoptic learners tend to rely on subconscious control; as a result, they bring the information together and "treat it all at once", while ectenics tend to rely on conscious control and divide or take apart information (Ehrman \& Leaver, 2003, p. 395). The ten subscales are (1) Field independence-Field dependence, (2) Field sensitivityField insensitivity, (3) Random-Sequential, (4) Global-Particular, (5) Inductive-Deductive, (6) Synthetic-Analytic, (7) Analogue-Digital, (8) Concrete-Abstract, (9) Leveling-Sharpening, and (10) Impulsive-Reflective. 
According to E\&L, a field independent learner tends to select and extract the important parts from its context, while a field dependent learner prefers to treat information in a more holistic way (Ehrman \& Leaver, 2003, p. 404). Ehrman and Leaver (2003) make a distinction between the terms field (in) dependence and field (in) sensitivity. In contrast to field independent learners who extract the important parts from context, a field sensitive learner sees the entire field as composed of interrelated segments. Field sensitive learners prefer to learn by interaction with the entire field or context; field insensitive learners, on the other hand, prefer not to make use of context but tend to learn language using isolated rules (Ehrman \& Leaver, 2003, p. 404).

Random learners tend to work out their own learning process and develop their own ways to learn a language, whereas sequential learners tend to follow the order which is provided by the textbook or syllabus. Global learners prefer to focus on the "big picture", whereas particular learners tend to focus on details and discrete items. In contrast to global learners, who place meaning on everything, particular learners prefer to move from form to meaning.

Inductive learners prefer to start with data and specific examples and then come up with general rules whereas deductive learners tend to study the rules and then apply them to the specific cases in front of them. Synthetic learners prefer to put the known facts and information together to build new wholes, whereas analytic learners tend to break down the wholes into smaller parts in order to explain phenomena.

Digital learners prefer to get meaning directly without explanation; analogue learners, in contrast, prefer to get meaning through metaphors and interpretation. Concrete learners tend to involve themselves with what is being learned and prefer real materials, whereas abstract learners tend to focus on grammar rules and system of language rather than language use for communication.

Levelers tend to oversimplify their perception of the task, that is, they ignore distinctions and only notice similarities, while sharpeners tend to notice distinctions and details. Individuals who tend to respond very quickly but often are less accurate are labeled as impulsives, while those who prefer to think and then respond and are often more accurate than the others are called reflectives.

\section{Studies on Cognitive Styles and Corrective Feedback}

As mentioned earlier a great deal of research has been conducted on the usefulness of WCF, however, these studies are often considered to be incomplete because they have not considered individual factors which seem to have an important role in the efficacy of feedback and writing development. According to Ellis (as cited in Rahimi, 2015), "the vast 
bulk of CF [corrective feedback] studies have ignored learner factors, focusing instead on the relationship and the effect of specific CF strategies and learning outcomes" (p. 20).

A set of studies, which addresses the issue investigated in the present study, has been conducted on the contribution of cognitive styles to the efficacy of corrective feedback. Darabad (2013) investigated the effect of two types of oral corrective feedback (prompts and recasts) on the oral accuracy of Iranian English as a foreign language (EFL) learners considering their cognitive styles in terms of field dependency. The result of the study revealed that there is no relationship between learners' cognitive styles and types of feedback in terms of target language accuracy. However, in another study Yoshida (2008) explored teachers' choice and learners' preferences for corrective feedback types. The findings of this study indicated that teachers chose different corrective feedback types according to learners' cognitive styles and language abilities.

In written context, Rahimi (2015) investigated the role of individual differences (field dependency and writing motivation) in the retention of teachers' WCF. He found that there was a strong relationship between learners' field dependency and their successful short-term and longterm retention of WCF. Writing motivation, however, had an impact on short-term retention only. Moreover, Shojaei and Kapfo (2015) explored the effects of cognitive style (field dependency) on English as a second language (ESL) learners' general writing ability. The findings of the study indicated that cognitive style has a significant effect on general writing ability.

\section{Method}

\section{Participants}

Sixty Iranian young adult learners, including 57 females and 3 males with an average age of 20, were selected randomly to participate in the present study. The participants of this study were native speakers of Kurdish and Persian but had studied English at institutions for several terms. All participants had taken a placement test in their institutions and had passed their English courses for several terms. They were qualified in intermediate and upper-intermediate exams. Due to the nature of the study and the learners' preferences for WCF, it was important that they be proficient enough in writing English. Therefore, the researchers selected the participants from among learners who had already passed courses on writing skills.

\section{Instruments}

The E\&L learning style questionnaire. In order to determine participants' cognitive styles, the Persian translation of E\&L Learning Style Questionnaire, developed by Ehrman 
and Leaver (2003), was used (see Appendix 1). This questionnaire consists of thirty statements which require the respondent to mark their preferences on a nine-point Likerttype scale. There are three items for each of the ten style dimensions. The ten subscales, based on the person's preferences, provide information about the learners' general stylistic orientation, represented by a superordinate scale of synoptic-ectenic. The reliability of the whole and each of the subscales of the Persian version of the questionnaire were investigated in previous studies (Maftoon \& Rezaie, 2011). The reliability of the whole questionnaire was 0.778 ; however, the reliability of subscales ranged between 0.571 and 0.853 . The data obtained from this questionnaire were used to identify cognitive styles of the participants.

Corrective feedback questionnaire. For the purpose of comparing learners' preferences for WCF, the researchers used a questionnaire constructed by Amrhein and Nassaji (2010) (see Appendix 2). All of the questionnaire items were based on previous studies (Amrhein \& Nassaji, 2010; Ferris, 1995; Leki, 1991; Saito, 1994), which increased the validity of the instrument. This questionnaire consists of three parts. Part A was used to elicit information about learners' preferences for different frequencies of error correction provided by the teacher. Section B provides information about learners' preferences for different types of WCF. Seven question items are represented by this part which requires the respondent to mark their preferences on a five-Likert scale. Six question items of the questionnaire refer to types of error, which are ranged in a five-Likert scale, and are represented by part C. Section $\mathrm{C}$ of the questionnaire was used to elicit information about learners' preferences for different types of their errors to be corrected by the teacher.

\section{Procedure}

To gather the relevant data, the two questionnaires were distributed to the participants at the institutions participating in this study and were completed at the time of distribution. Detailed instructions were given by the researchers on how to complete the questionnaires.

First, in order to divide participants into two groups of synoptic and ectenic, the E\&L Learning Style Questionnaire was administered. During the E\&L Learning Style Questionnaire, the participants were required to finish 30 items within a specific time limit. They were asked to mark their preferences on a nine-point Likert scale. Then, in order to compare synoptic and ectenic learners' preferences for WCF, the student's questionnaire was administered and both groups of participants were asked to choose the best description in terms of usefulness for different frequencies and each type of feedback and error to be corrected.

\section{Data Analysis}

Learners were codified as either synoptic or ectenic based on their responses on the E\&L Learning Styles Questionnaire, and then compared in terms of their preferences for WCF. 
The questionnaire responses were recorded in an Excel spreadsheet and then were imported to SPSS 18.0 for statistical analysis. To analyze the data for the second research question, as the data obtained from the two variables were nominal, the researchers used the Chi-square formula to find out the association between the two variables. For the questionnaire items that included Likert scales, the association between the two variables was determined by means of Point Bi-serial Correlation Coefficient.

\section{Results}

\section{Learners' Cognitive Style and Types of Feedback}

Table 1 shows the frequency and percent of the learners with respect to their cognitive styles. The results obtained from descriptive statistics showed that $62 \%$ of the learners had a synoptic cognitive style and $38 \%$ of them had an ectenic cognitive style. The total number of students was 60 .

Table 1. Frequency and Percent of Cognitive Styles

\begin{tabular}{|l|l|r|r|r|r|}
\hline \multicolumn{2}{|c|}{} & Frequency & Percent & Valid Percent & $\begin{array}{c}\text { Cumulative } \\
\text { Percent }\end{array}$ \\
\hline \multirow{4}{*}{ Valid } & Synoptic & 37 & 61.7 & 61.7 & 61.7 \\
\cline { 2 - 6 } & Ectenic & 23 & 38.3 & 38.3 & 100.0 \\
\cline { 2 - 6 } & Total & 60 & 100.0 & 100.0 & \\
\hline
\end{tabular}

In order to answer the first research question, the Point bi-serial Correlation Coefficient Formula was performed.

Table 2. The Correlation Between Cognitive Style and Type of Feedback

\begin{tabular}{|l|l|c|c|}
\hline \multicolumn{2}{|c|}{} & Cognitive style & $\begin{array}{c}\text { Type of } \\
\text { feedback }\end{array}$ \\
\hline \multirow{3}{*}{ Cognitive style } & Pearson Correlation & 1 & .563 \\
\cline { 2 - 4 } & Sig. (2-tailed) & & .046 \\
\cline { 2 - 4 } & $N$ & 60 & 60 \\
\hline \multirow{3}{*}{ Type of feedback } & Pearson Correlation & .563 & 1 \\
\cline { 2 - 4 } & Sig. (2-tailed) & .046 & \\
\cline { 2 - 4 } & $N$ & 60 & 60 \\
\hline
\end{tabular}


The results (see Table 2) showed the relationship between learners' cognitive style and scores obtained from their preferences for different types of written corrective feedback was statistically significant $[r=.56, n=60, p<.05]$.

Table 3. Frequency and Percent of Synoptic Style for Type of Feedback

\begin{tabular}{|c|l|c|c|c|c|}
\hline \multicolumn{2}{|c|}{} & Frequency & Percent & $\begin{array}{c}\text { Valid } \\
\text { Percent }\end{array}$ & $\begin{array}{c}\text { Cumulative } \\
\text { Percent }\end{array}$ \\
\hline \multirow{5}{*}{ Valid } & Clues or direction & 132 & 18.0 & 18.0 & 18.0 \\
\cline { 2 - 6 } & Error identification & 86 & 11.7 & 11.7 & 29.7 \\
\cline { 2 - 6 } & $\begin{array}{l}\text { Correction with } \\
\text { comments }\end{array}$ & 150 & 20.4 & 20.4 & 50.1 \\
\cline { 2 - 6 } & $\begin{array}{l}\text { Overt correction } \\
\text { Commentary } \\
\text { (comment with } \\
\text { no correction) }\end{array}$ & 127 & 17.3 & 17.3 & 67.3 \\
\cline { 2 - 6 } & No feedback & 115 & 15.6 & 15.6 & 83.0 \\
\cline { 2 - 6 } & $\begin{array}{l}\text { Personal comments } \\
\text { on content }\end{array}$ & 57 & 7.8 & 7.8 & 90.7 \\
\hline & Total & 735 & 100.0 & 100.0 & 100.0 \\
\hline
\end{tabular}

Table 3 shows the frequency and percent of type of feedback selected by synoptic cognitive style learners. As the results showed, the percentages from the most to the least were as follows: (1) Correction with comments (20.4\%), (2) Clue or direction (18\%), (3) Overt correction (17.3\%), (4) Commentary (15.6\%), (5) Error identification (11.7\%), (6) Personal comments (9.3\%), and (7) No feedback (7.8\%).

Table 4. Frequency and Percent of Ectenic Style for Type of Feedback

\begin{tabular}{|c|l|c|c|c|c|}
\hline \multicolumn{2}{|c|}{} & Frequency & Percent & $\begin{array}{c}\text { Valid } \\
\text { Percent }\end{array}$ & $\begin{array}{c}\text { Cumulative } \\
\text { Percent }\end{array}$ \\
\hline \multirow{4}{*}{ Valid } & Clues or direction & 80 & 16.8 & 16.8 & 16.8 \\
\cline { 2 - 5 } & Error identification & 50 & 10.5 & 10.5 & 27.3 \\
\cline { 2 - 5 } & Correction with comments & 103 & 21.6 & 21.6 & 48.8 \\
\cline { 2 - 6 } & Overt correction & 86 & 18.0 & 18.0 & 66.9 \\
\cline { 2 - 6 } & Commentary (comment with no correction) & 82 & 17.2 & 17.2 & 84.1 \\
\cline { 2 - 6 } & No feedback & 31 & 6.5 & 6.5 & 90.6 \\
\cline { 2 - 6 } & Personal comments on content & 45 & 9.4 & 9.4 & 100.0 \\
\hline & Total & 477 & 100.0 & 100.0 & \\
\hline
\end{tabular}


Table 4 shows the frequency and percent of types of feedback preferred by ectenic learners. As the results showed, the percentages from the most to the least were as follows: (1) Correction with comments (21.6\%), (2) Overt correction (18\%), (3) Commentary (17.2\%), (4) Clues or direction (16.8\%), (5) Error identification (10.5\%), (6) Personal comments (9.4\%), (7) No feedback (6.5\%).

\section{Learners' Cognitive Style and Frequency of Error Correction}

To test the second research hypothesis concerning the relationship between learners' cognitive styles and their preferences for different frequencies of error correction, the Chisquare Formula was performed.

Table 5. Number of Cases for Cognitive Style and the Frequency of Error Correction

\begin{tabular}{|l|l|c|c|c|c|c|c|}
\hline \multicolumn{2}{|c|}{} & \multicolumn{5}{|c|}{ Frequency of error correction } & \multirow{2}{*}{ Total } \\
\cline { 3 - 7 } & All errors & $\begin{array}{c}\text { Major } \\
\text { errors }\end{array}$ & $\begin{array}{c}\text { Most of } \\
\text { the major } \\
\text { errors }\end{array}$ & $\begin{array}{c}\text { A few of } \\
\text { the major } \\
\text { errors }\end{array}$ & $\begin{array}{c}\text { Errors } \\
\text { that } \\
\text { interfere }\end{array}$ & \\
\hline $\begin{array}{l}\text { Cognitive } \\
\text { style }\end{array}$ & Synoptic & 20 & 9 & 2 & 2 & 4 & 37 \\
\cline { 2 - 7 } & Ectenic & 9 & 6 & 5 & 0 & 3 & 23 \\
\hline \multicolumn{2}{|l|}{ Total } & 29 & 15 & 7 & 2 & 7 & 60 \\
\hline
\end{tabular}

As indicated in Table 5, out of 37 learners who had the synoptic style, most of them $(N$ $=20$ ) believed that teachers should mark all errors, and nine of them believed that teachers should mark all major errors but not the minor errors. Similarly, as for the ectenic cognitive style, out of 23 students, most of them $(N=9)$ believed that teachers should mark all errors, and six of them believed that teachers should mark all major errors but not the minor errors.

Table 6. Chi-Square Tests for Frequency of Error Correction

\begin{tabular}{|l|c|c|c|}
\hline & Value & $d f$ & $\begin{array}{c}\text { Asymp. Sig. (2 } \\
\text { sided) }\end{array}$ \\
\hline Pearson Chi-Square & $5.218^{\mathrm{a}}$ & 4 & .266 \\
\hline Likelihood Ratio & 5.830 & 4 & .212 \\
\hline Linear-by-Linear Association & .577 & 1 & .447 \\
\hline N of Valid Cases & 60 & & \\
\hline
\end{tabular}

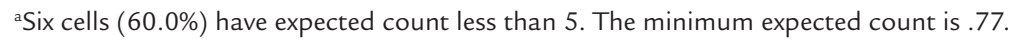

Table 6 indicates that the relationship between learners' cognitive styles and their preferences for different frequencies of error correction was not significant. 


\section{Learners' Cognitive Style and Types of Errors}

To answer the last research question concerning the relationship between cognitive styles and learners' preferences for different types of errors to be corrected, the Point biserial correlation coefficient was performed.

Table 7. The Correlation Between Cognitive Style and Type of Errors

\begin{tabular}{|l|l|c|c|}
\hline \multicolumn{2}{|c|}{} & Cognitive style & Type of error \\
\hline \multirow{4}{*}{ Cognitive style } & Pearson correlation & 1 & .973 \\
\cline { 2 - 4 } & Sig. (2-tailed) & & .004 \\
\cline { 2 - 4 } & $\mathrm{N}$ & 60 & 60 \\
\hline \multirow{3}{*}{ Type of error } & Pearson correlation & .973 & 1 \\
\cline { 2 - 4 } & Sig. (2-tailed) & .004 & \\
\cline { 2 - 4 } & $\mathrm{N}$ & 60 & 60 \\
\hline
\end{tabular}

The results (see Table 7) showed that the relationship between learners' cognitive style and scores obtained from their preferences for different types of their errors to be corrected was statistically significant $[r=.97, n=60, p<.05]$.

Table 8. Frequency and Percent of Synoptic Style for Type of Errors

\begin{tabular}{|c|l|c|c|c|c|}
\hline \multicolumn{2}{|c|}{} & Frequency & Percent & $\begin{array}{c}\text { Valid } \\
\text { Percent }\end{array}$ & $\begin{array}{c}\text { Cumulative } \\
\text { Percent }\end{array}$ \\
\hline \multirow{4}{*}{ Valid } & Organization errors & 139 & 17.0 & 17.0 & 17.0 \\
\cline { 2 - 6 } & Grammatical errors & 162 & 19.9 & 19.9 & 36.9 \\
\cline { 2 - 6 } & Content/idea errors & 124 & 15.2 & 15.2 & 52.1 \\
\cline { 2 - 6 } & Punctuation errors & 121 & 14.8 & 14.8 & 66.9 \\
\cline { 2 - 6 } & Spelling errors & 127 & 15.6 & 15.6 & 82.5 \\
\cline { 2 - 6 } & Vocabulary errors & 143 & 17.5 & 17.5 & 100.0 \\
\hline \multirow{2}{*}{} & Total & 816 & 100.0 & 100.0 & \\
\hline
\end{tabular}

Table 8 shows the frequency and percent of type of error selected by synoptic learners. As the results showed, the percentages from the most to the least were as follows: (1) Grammatical errors (19.9\%), (2) Vocabulary errors (17.5\%), (3) Organization errors (17.0\%), (4) Spelling errors (15.6\%), (5) Content or idea errors (15.2\%), and (6) Punctuation errors $(14.8 \%)$. 
Table 9. Frequency and Percent of Ectenic Style for Type of Errors

\begin{tabular}{|c|l|c|c|c|c|}
\hline \multicolumn{2}{|c|}{} & Frequency & Percent & $\begin{array}{c}\text { Valid } \\
\text { Percent }\end{array}$ & $\begin{array}{c}\text { Cumulative } \\
\text { Percent }\end{array}$ \\
\hline \multirow{4}{*}{ Valid } & Organization errors & 89 & 17.5 & 17.5 & 17.5 \\
\cline { 2 - 6 } & Grammatical errors & 102 & 20.1 & 20.1 & 37.6 \\
\cline { 2 - 6 } & Content/idea errors & 68 & 13.4 & 13.4 & 51.0 \\
\cline { 2 - 6 } & Punctuation errors & 71 & 14.0 & 14.0 & 65.0 \\
\cline { 2 - 6 } & Spelling errors & 81 & 15.9 & 15.9 & 80.9 \\
\cline { 2 - 6 } & Vocabulary errors & 97 & 19.1 & 19.1 & 100.0 \\
\hline \multirow{2}{*}{} & Total & 508 & 100.0 & 100.0 & \\
\hline
\end{tabular}

Table 9 shows the frequency and percent of types of errors preferred by ectenic learners. As the results showed, the percentages from the most to the least were as follows: (1) Grammatical errors (20.1\%), (2) Vocabulary errors (19.1\%), (3) Organization errors (17.5\%), (4) Spelling errors (15.9\%), (5) Punctuation errors (14\%), and (6) Content errors (13.4\%).

\section{Discussion}

In this research, the major focus was on finding a relationship between learners' cognitive styles and their preferences for WCF. In response to the first research question, the results confirmed a relationship between synoptic-ectenic cognitive styles and learners' preferences for different types of corrective feedback. As for the third question, the results showed a relationship between learners' cognitive styles and their preferences for different types of errors to be corrected. The findings are in line with Brown (2007), Ellis (2012), Mackey, Philp, Egi, Fujii, and Tatsumi (2002), and Robinson (2002), who considered an important role for individual factors (especially cognitive and affective factors) as significant factors that mediate between instruction and L2 learning. The findings are also congruent with Yoshida's work (2008), which stated that teachers chose different corrective feedback types according to learners' cognitive styles and language ability. The results also confirm Rahimi's (2015) finding that showed a positive effect for cognitive factors on the retention of teachers' corrective feedback.

In response to the first research question, the findings showed that the most preferred type of feedback for both synoptic and ectenic learners was correction with comments. However, the mean responses of the perception of synoptic and ectenic learners showed that both groups disagree with no correction. The second preferred type of feedback for synoptic learners was providing clues or direction $(18 \%)$, while the perception of ectenic 
learners toward overt correction (18\%) and commentary (17.2\%) was more positive than their attitude toward providing clues or direction $(16.2 \%)$. The result is in line with the predictions made by Ehrman and Leaver (2003) and Dörnyei (2005). As they argue, synoptic learners tend to rely on subconscious control, whereas ectenic learners prefer to rely on conscious control. In line with their prediction, and regarding Ellis's (2009) typology of corrective feedback, the results obtained from this study showed that synoptic learners preferred indirect correction, while ectenics preferred to be corrected directly.

In response to the second research question the results showed no significant relationship between synoptic and ectenic cognitive styles and learners' preferences for different frequencies of error correction. As Ehrman and Leaver (2003) reported that synoptic learners are often both field independent and field sensitive, so they are more autonomous, it was expected that they preferred less correction to be provided on their written works. In contrast to this prediction, the majority of both groups believed that the teacher should mark all of their errors. The lack of a statistically significant relationship between synopticectenic cognitive styles and learners' preferences for different frequencies of providing corrective feedback can be explained in this way: previous research has shown that most learners (regardless of their individual differences) prefer to receive teachers' feedback on their writing (Ferris, 1995; Ferris \& Roberts, 2001; Hedgcock \& Lefkowitz, 1994; Hyland, 1998; Lee, 2004; Leki, 1991; Zacharias, 2007).

\section{Conclusion and Implications}

The findings of this study contribute to corrective feedback literature, and also reveal some pedagogical implications for EFL teachers. In order to plan their instructional methods and adopt the most suitable feedback approach, teachers need to be aware of the important role played by their learners' needs and individual characteristics in the learning process (Ferris, Liu, Sinha, \& Senna as cited in Rahimi, 2015).

Since the results of this study confirmed a relationship between learners' cognitive styles and their preferences for different types of WCF, teachers need to identify their students' individual styles and match their instruction methods with learners' learning styles.

More specifically, the findings showed that the most preferred type of feedback for both synoptic and ectenic learners was correction with comments. The second preferred type of feedback for synoptic learners was providing clues or direction; however, the perception of ectenic learners toward overt correction and commentary was more positive than their attitude toward providing clues or direction. Therefore, it can be concluded that synoptic learners prefer indirect feedback, while ectenics prefer to be corrected directly. 
The results also confirmed a relationship between learners' cognitive styles and their preferences for different types of errors to be corrected. The most preferred type of learners' errors for both groups was grammatical errors. The perception of ectenic learners toward the correction of vocabulary errors was more positive than that of the synoptics. However synoptic learners found the correction of content errors more useful than ectenics. In other words, ectenic learners preferred teachers' feedback on form, but synoptic learners preferred to receive feedback on content. Therefore, teachers need to adopt a focused method of feedback and select one or two specific types of errors, including both content and structural errors for different learners.

The results of this study, however, showed no significant relationship between learners' cognitive styles and their preferences for different frequencies of error correction. The majority of both synoptic and ectenic learners believed that teachers should mark all errors, and the least preferred option for both groups was no feedback at all. It can be concluded that most learners (regardless of individual differences among them) value teachers' feedback on their written works.

\section{References}

Amrhein, H. R., \& Nassaji, H. (2010). Written corrective feedback: What do students and teachers prefer and why? Canadian Journal of Applied Linguistics, 13, 95-127.

Boughey, C. (1997). Learning to write by writing to learn: a group-work approach. ELT Journal, 51(2), 126-134. http://doi.org/10.1093/elt/51.2.126.

Brown, H. D. (2000). Principles of language learning and teaching (4th ed.). New York, US: Addison Wesley Longman.

Brown, H. D. (2007). Teaching by principles: An interactive approach to language pedagogy (3rd ed.). White Plains, US: Pearson Education.

Curry, L. (1983). An organization of learning styles theory and constructs. Retrieved from ERIC database. (ED235185)

Darabad, A. M. (2013). Does language aptitude make a difference? An investigation of the effect on oral accuracy through corrective feedback. International Journal of Linguistics, 5(4), 225-244. http://doi.org/10.5296/ijl.v5i4.4199.

Dörnyei, Z. (2005). The psychology of the language: Individual differences in second language acquisition. Mahwah, US: Lawrence Erlbaum.

Ehrman, M., \& Leaver, B. L. (2003). Cognitive styles in the service of language learning. System, 31(3), 393-415. http://doi.org/10.1016/S0346-251X(03)00050-2.

Ellis, R. (2009). A typology of written corrective feedback types. English Language Teaching Journal, 63(2), 97-107. http://doi.org/10.1093/elt/ccn023. 
Ellis, R. (2012). Language teaching research and language pedagogy. Oxford, UK: Wiley Blackwell. http:// doi.org/10.1002/9781118271643.

Ferris, D. R. (1995) Student reactions to teacher response in multiple-draft composition classrooms. TESOL Quarterly, 29(1), 33-53. http://doi.org/10.2307/3587804.

Ferris, D. R. (1999). The case for grammar correction in L2 writing classes: A response to Truscott (1996). Journal of Second Language Writing, 8(1), 1-11. http://doi.org/10.1016/S10603743(99)80110-6.

Ferris, D. R. (2003). Response to student writing: Implications for second language students. Mahwah, US: Lawrence Erlbaum.

Ferris, D. R. (2004). The "grammar correction" debate in L2 writing: Where are we, and where do we go from here? (and what do we do in the meantime...?). Journal of Second Language Writing, 13(1), 49-62. http://doi.org/10.1016/j.jslw.2004.04.005.

Ferris, D. R. (2010). Second language writing research and written corrective feedback in SLA: Intersections and practical applications. Studies in Second Language Acquisition, 32(2), 181-201. http://doi.org/10.1017/S0272263109990490.

Ferris, D. R., \& Roberts, B. (2001). Error feedback in L2 writing classes: How explicit does it need to be? Journal of Second Language Writing, 10(3), 161-184. http://doi.org/10.1016/S10603743(01)00039-X.

Hedgcock, J., \& Lefkowitz, N. (1994). Feedback on feedback: Assessing learner receptivity in second language writing. Journal of Second Language Writing, 3(2), 141-163. http:/ / doi.org/10.1016/10603743(94)90012-4.

Hyland, F. (1998). The impact of teacher written feedback on individual writers. Journal of Second Language Writing, 7(3), 255-286. http://doi.org/10.1016/S1060-3743(98)90017-0.

Kepner, C. G. (1991). An experiment in the relationship of types of written feedback to the development of second-language writing skills. The Modern Language Journal, 75(3), 305-315. http:/ / doi.org/10.1111/j.1540-4781.1991.tb05359.x.

Larsen-Freeman, D., \& Long, M. H. (1991). An introduction to second language acquisition research. New York, US: Longman.

Lee, I. (1997). ESL learners' performance in error correction in writing: Some implications for college- level teaching. System, 25(4), 465-477. http://doi.org/10.1016/S0346-251X(97)00045-6.

Lee, I. (2004). Error correction in L2 secondary writing classroom: The case of Hong Kong. Journal of Second Language Writing, 13(4), 285-312. http://doi.org/10.1016/j.jslw.2004.08.001.

Leki, I. (1991). The preferences of ESL students for error correction in college-level writing classes. Foreign Language Annals, 24(3), 203-218. http://doi.org/10.1111/j.1944-9720.1991. tb00464.x.

Lightbown, P. M., \& Spada, N. (1999). How languages are learned. Oxford, UK: Oxford University Press. 
Lyster, R., \& Ranta, L. (1997). Corrective feedback and learner uptake: Negotiation of form in communicative classrooms. Studies in Second Language Acquisition, 19(1), 37-66. http://doi. org/10.1017/S0272263197001034.

Mackey, A., Philp, J., Egi, T., Fujii, A., \& Tatsumi, T. (2002). Individual differences in working memory, noticing of interactional feedback and L2 development. In P. Robinson (Ed.), Individual differences and instructed language learning (pp. 181-210). Amsterdam, NL: John Benjamins. http://doi.org/10.1075/1llt.2.12mac.

Maftoon, P., \& Rezaie, G. (2011). Cognitive style, awareness, and learners' intake and production of grammatical structures. Journal of Language and Translation, 3(3), 1-15.

Rahimi, M. (2009). The role of teacher's corrective feedback in improving Iranian EFL learners' writing accuracy over time: Is learners' mother tongue relevant? Reading and Writing, 22(2), 219-243. http://doi.org/10.1007/s11145-008-9139-5.

Rahimi, M. (2015). The role of individual differences in learners' retention of written corrective feedback. Journal of Response to Writing, 1(1), 19-48.

Riding, R. J., \& Cheema, I. (1991). Cognitive styles: an overview and integration. Educational Psychology, 11(3-4), 193-215. http://doi.org/10.1080/0144341910110301.

Roberts, B. (1999). Can error logs raise more than consciousness? The effects of error logs and grammar feedback on ESL students' final drafts (Unpublished Master's thesis). California State University, Sacramento, USA.

Robinson, P. (2002). Individual differences and instructed language learning. Amsterdam, NL: John Benjamins. http://doi.org/10.1075/1llt.2.

Saito, H. (1994). Teachers' practices and students' preferences for feedback on second language writing: A case study of adult ESL learners. TESL Canada Journal, 11(2), 46-70. http://doi. org/10.18806/tesl.v11i2.633.

Semke, H. D. (1984). Effects of the red pen. Foreign Language Annals, 17(3), 195-202. http://doi. org/10.1111/j.1944-9720.1984.tb01727.x.

Sheppard, K. (1992). Two feedback types: Do they make a difference? RELC Journal, 23, 103-110. http://doi.org/10.1177/003368829202300107.

Shojaei, F., \& Kapfo, K. (2015). A study of cognitive styles effect on ESL students' general writing ability. International Journal of Research, 2(9), 94-99.

Truscott, J. (1996). The case against grammar correction in L2 writing classes. Language Learning, 46(2), 327-369. http://doi.org/10.1111/j.1467-1770.1996.tb01238.x.

Truscott, J. (1999). The case for "The case against grammar correction in L2 writing classes": A response to Ferris. Journal of Second Language Writing, 8(2), 111-122. http://doi.org/10.1016/ S1060-3743(99)80124-6.

Yoshida, R. (2008). Teachers' choice and learners' preference of corrective feedback types. Language Awareness, 17(1), 78-93. http://doi.org/10.2167/la429.0. 
Zacharias, N. T. (2007). Teacher and student attitudes toward teacher feedback. RELC Journal, 38(1), 38-52. http://doi.org/10.1177/0033688206076157.

\section{The Authors}

Negar Moslemi has received her MA in TEFL from Azad University, Sanandaj Branch. She has been teaching English language in different institutes for more than three years.

Adel Dastgoshadeh holds a PhD in TEFL. He is an assistant professor at Islamic Azad University, Sanandaj Branch. His research interests include sociolinguistics, psycholinguistics, and teacher education. 


\section{Appendix 1: The E\&L Learning Styles Questionnaire}

Name:

Date:

1. When I work with new language in context, in stories or articles or with sentences, I I don't usually get much from the context unless often pick up new words, ideas, etc., without I pay close attention to what I'm doing. planning in advance.

Most like this Most like this

\section{$\begin{array}{lllllllll}1 & 2 & 3 & 4 & 5 & 6 & 7 & 8 & 9\end{array}$}

2. When working with new material with When there is a lot of information that comes additional subject matter around it, I with what I need to learn, it's hard to tell what's comfortably find and use what is most most important. It all seems to fall together important. sometimes, and it's hard work to sort things out.

Most like this Most like this

$\begin{array}{lllllllll}1 & 2 & 3 & 4 & 5 & 6 & 7 & 8 & 9\end{array}$

3. I like to reduce differences and look for I like to explore differences and disparities similarities. among things.

Most like this Most like this

$$
\begin{array}{lllllllll}
1 & 2 & 3 & 4 & 5 & 6 & 7 & 8 & 9
\end{array}
$$

4. I tend to be most aware of the "big picture". I notice specifics and details quickly.

Most like this Most like this

$\begin{array}{lllllllll}1 & 2 & 3 & 4 & 5 & 6 & 7 & 8 & 9\end{array}$

5. I react quickly.

I take my time to react.

Most like this Most like this $\begin{array}{lllllllll}1 & 2 & 3 & 4 & 5 & 6 & 7 & 8 & 9\end{array}$

6. I understand best by assembling what I'm I understand best by disassembly of what I'm learning into a whole. learning into its component parts.

Most like this Most like this

\section{$\begin{array}{lllllllll}1 & 2 & 3 & 4 & 5 & 6 & 7 & 8 & 9\end{array}$}


7. I tend to learn things through metaphors. I like it when people say what they mean directly.

Most like this Most like this

$\begin{array}{lllllllll}1 & 2 & 3 & 4 & 5 & 6 & 7 & 8 & 9\end{array}$

8. To learn, I like to interact with the world. I like to learn through concepts and ideas.

Most like this Most like this

$\begin{array}{lllllllll}1 & 2 & 3 & 4 & 5 & 6 & 7 & 8 & 9\end{array}$

9. I learn best when I can work out for myself the best sequence to use, even if it's different from the one in the book or lesson.

I learn best when there is a sequence of steps provided, so I can do things in order.

Most like this Most like this

\section{$\begin{array}{lllllllll}1 & 2 & 3 & 4 & 5 & 6 & 7 & 8 & 9\end{array}$}

10. When I learn, I mostly start with examples When I learn, I mostly start with rules and or my experience and make generalizations generalizations and apply them to my experience or rules. to learn.

Most like this Most like this

$$
\begin{array}{lllllllll}
1 & 2 & 3 & 4 & 5 & 6 & 7 & 8 & 9
\end{array}
$$

11. I often find that I have picked up new words, I usually have to undertake focused study before phrases, and so on without realizing it. I learn new words or phrases.

Most like this Most like this

$$
\begin{array}{lllllllll}
1 & 2 & 3 & 4 & 5 & 6 & 7 & 8 & 9
\end{array}
$$

12. I like out-of-context material like grammar Grammar rules and pieces of language that are rules. out of context are hard for me to work with.

Most like this Most like this

\section{$\begin{array}{lllllllll}1 & 2 & 3 & 4 & 5 & 6 & 7 & 8 & 9\end{array}$}

13. I notice mostly how things are similar.

I quickly notice differences, even fairly fine distinctions.

Most like this Most like this

$$
\begin{array}{lllllllll}
1 & 2 & 3 & 4 & 5 & 6 & 7 & 8 & 9
\end{array}
$$



14. I notice the "forest" before the "trees". $\quad \begin{aligned} & \text { I tend to be aware of the "trees" before the } \\ & \text { "forest". }\end{aligned}$

Most like this Most like this

\section{$\begin{array}{lllllllll}1 & 2 & 3 & 4 & 5 & 6 & 7 & 8 & 9\end{array}$}

15. I don't have to spend much time preparing for something; instead, I start off working immediately.

Before starting anything, I want time to orient myself to it.

Most like this Most like this

$$
\begin{array}{lllllllll}
1 & 2 & 3 & 4 & 5 & 6 & 7 & 8 & 9
\end{array}
$$

16. I often make up new words or sentences using language I already know.

I seek to understand the system that is behind words and sentences by pulling them apart in my mind.

Most like this Most like this

$$
\begin{array}{lllllllll}
1 & 2 & 3 & 4 & 5 & 6 & 7 & 8 & 9
\end{array}
$$

17. I prefer to learn by using lots of associations. I prefer to use rehearsal and repetition to learn.

Most like this Most like this

$$
\begin{array}{lllllllll}
1 & 2 & 3 & 4 & 5 & 6 & 7 & 8 & 9
\end{array}
$$

18. I like to learn through applying knowledge I like to learn through descriptions and grammar and theory. that formally represent knowledge.

Most like this Most like this

$$
\begin{array}{lllllllll}
1 & 2 & 3 & 4 & 5 & 6 & 7 & 8 & 9
\end{array}
$$

19. Too much emphasis on a curriculum or Organized textbooks and lesson plans reatextbook can get in the way of my learning. lly help me.

Most like this Most like this

$$
\begin{array}{lllllllll}
1 & 2 & 3 & 4 & 5 & 6 & 7 & 8 & 9
\end{array}
$$

20. I like to figure out grammar rules for myself. $\begin{aligned} & \text { I prefer to get the grammar rules from the } \\ & \text { teacher or a book. }\end{aligned}$ Most like this Most like this

$$
\begin{array}{lllllllll}
1 & 2 & 3 & 4 & 5 & 6 & 7 & 8 & 9
\end{array}
$$


21. I learn best from language that is in meaningful context like stories and conversations.
I don't like to have to learn from just conversations, informal language use, or readings for native speakers that I haven't been prepared for.

Most like this Most like this

$$
\begin{array}{lllllllll}
1 & 2 & 3 & 4 & 5 & 6 & 7 & 8 & 9
\end{array}
$$

22. When faced with new language, I reconceptualize it so that it makes sense in my own terms.

I accept what is presented to me and take it pretty much as presented.

Most like this Most like this

$$
\begin{array}{lllllllll}
1 & 2 & 3 & 4 & 5 & 6 & 7 & 8 & 9
\end{array}
$$

23. I tend not to remember small distinctions, I have a good memory for fine distinctions such as those between similar-seeming such as those between similar-seeming words or words or symbols. symbols.

Most like this Most like this

$$
\begin{array}{lllllllll}
1 & 2 & 3 & 4 & 5 & 6 & 7 & 8 & 9
\end{array}
$$

24. I start with the main points and work down I begin with the details to work up to the to the details. main points.

Most like this Most like this

$$
\begin{array}{lllllllll}
1 & 2 & 3 & 4 & 5 & 6 & 7 & 8 & 9
\end{array}
$$

25. I often act or speak without thinking about I tend to think about things before I do or say it. them.

Most like this Most like this

$$
\begin{array}{lllllllll}
1 & 2 & 3 & 4 & 5 & 6 & 7 & 8 & 9
\end{array}
$$

26. I sometimes make up new ways to say things. $\begin{aligned} & \text { I prefer figuring } \\ & \text { are put together. }\end{aligned}$

Most like this Most like this

$$
\begin{array}{lllllllll}
1 & 2 & 3 & 4 & 5 & 6 & 7 & 8 & 9
\end{array}
$$


27. It helps to understand the meanings behind It's usually okay to take what I'm learning at face the actual words. value.

Most like this Most like this

$\begin{array}{lllllllll}1 & 2 & 3 & 4 & 5 & 6 & 7 & 8 & 9\end{array}$

28. I like learning when I can touch, see, or hear. I prefer to learn abstractly through theories.

Most like this Most like this

$\begin{array}{lllllllll}1 & 2 & 3 & 4 & 5 & 6 & 7 & 8 & 9\end{array}$

29. It doesn't matter if the material I'm learning isn't very organized; I can find a way to use It's important to go step-by-step as I learn. it.

Most like this Most like this

$$
\begin{array}{lllllllll}
1 & 2 & 3 & 4 & 5 & 6 & 7 & 8 & 9
\end{array}
$$

30. When learning, I make guesses and then seek evidence to confirm or modify my ideas.

When learning, I would rather learn what I need to know directly, without fumbling around.

Most like this Most like this

$\begin{array}{lllllllll}1 & 2 & 3 & 4 & 5 & 6 & 7 & 8 & 9\end{array}$




\section{Appendix 2: Corrective Feedback Questionnaire}

A. If there are many errors in your writing, what do you think your English teacher should do?

1. $\square$ Teacher should mark all errors.

2. $\square$ Teacher should mark all major errors not the minor errors.

3. $\square$ Teacher should mark most of the major errors but not necessarily all of them.

4. $\square$ Teacher should mark only a few of the major errors.

5. $\square$ Teacher should mark only the errors that interfere with communicating ideas.

6. $\square$ Teacher should mark no errors and respond only to the ideas and content.

B. The following sentences all have the same error and a teacher has given a different type of feedback for each. For each sentence circle the number that best describes how useful the feedback is: (for example, if you think the feedback is a very useful way to point out an error then circle 5. If you think the feedback is not a useful way to point out an error then circle 1.)

$1=$ not useful at all, $2=$ not useful, $3=$ doesn't matter, $4=$ quite useful, $5=$ very useful

a) Since I arrived in Tehran, I am very lonely. Look at Section 2 in grammar book. 12345

b) Since I arrived in Tehran, I am very lonely. 12345

c) Since I arrived in Tehran, I am very lonely. have been (wrong tense). 12345

d) Since I arrived in Tehran, I am very lonely. have been. 12345

e) Since I arrived in Tehran, I am very lonely. wrong tense. 12345

f) Since I arrived in Tehran, 1 am very lonely. 12345

g) Since I arrived in Tehran, I am very lonely. I'm sorry to bear that. 12345

C. If there are many different errors in your writing, which type(s) of errors do you want your English teacher to point out most? (circle one number that best describes each statement)

$1=$ not useful at all, $2=$ not useful, $3=$ doesn't matter, $4=$ quite useful, $5=$ very useful.

a) The teacher should point out organization errors. $\quad \underline{12345}$

(example: paragraph structure, sentence order) 
b) The teacher should point out grammatical errors. $\quad \underline{12345}$ (example: tense, word order, sentence structure)

c) The teacher should point out content/idea errors. $\quad \underline{12345}$ (example: comments on your ideas)

d) The teacher should point out punctuation errors. $\quad \underline{12345}$ (example: ?, "”)

e) The teacher should point out spelling errors. $\quad \underline{12345}$

f) The teacher should point out vocabulary errors. $\quad \underline{12345}$ (example: wrong word choice, word meaning)

g) Other: $\underline{12345}$ 